\title{
The Apolitical Lawyer: Experimental Evidence of a Framing Effect
}

\author{
Michal Ovádek*
}

October 21, 2019

\begin{abstract}
Behavioural law and economics has established a burgeoning research agenda investigating the impact of bias and heuristics on legal decision-making. One of the most important behavioural contributions concerns the impact of framing on choice. The present article expands this line of scholarship by developing a novel hypothesis under which lawyers' attachment to objectivity and neutrality is assumed to militate against frames challenging the profession's underlying norms. More specifically, the 'apolitical hypothesis' expects the attachment of legally irrelevant political motivation to legal arguments to decrease their attractiveness. The hypothesis is tested in an experimental setting accounting for a varying degree of legal indeterminacy in the domain of European Union law. The experimental results show support for the hypothesis: a political frame made law students $12 \%$ to $24 \%$ more likely to select the 'apolitical' legal option.

Keywords: legal experiments, behavioural law and economics, framing, ambiguity, European Union law

JEL Classification: K49; C92; D91
\end{abstract}

Acknowledgment The author gratefully acknowledges financial support from European Research Council Grant No. 638154 (EUTHORITY).

* Centre for Legal Theory and Empirical Jurisprudence, Faculty of Law, KU Leuven, Belgium. Email: michal. ovadek@kuleuven. be 


\section{Introduction}

The integration of cognitive psychology into law and economics has sparked a fruitful (Jolls et al., 1998; Korobkin and Ulen, 2000) and disruptive (Rachlinski, 2011; Sheffrin, 2017) research agenda. A growing body of evidence emerging over the past three decades has demonstrated how decision-making of legal practitioners - judges, lawyers, clerks - falls prey to various heuristics and biases (Gigerenzer and Engel, 2006; Guthrie et al., 2001). A great deal of this scholarship has been produced in the common law context - notably the United States - while focusing on distortions in cognitive abilities to make quantitative judgments (Robbennolt, 1999; Guthrie et al., 2001; Rachlinski et al., 2015). The interest in an individual's numerical skills has not only methodological appeal but also a long-standing pedigree in behavioural research (Tversky and Kahneman, 1974, 1981).

Without taking anything away from the importance of the existing behavioural law and economics research programme, the most distinctive cognitive processes relating to legal practice concern the selection, interpretation and application of rules and standards (Schauer, 2010; Gillman, 2001). These processes take place in the heads of legal practitioners on an everyday basis when they are called on to engage with a legal question or problem, which often occurs in writing. Studying the impact of heuristics and biases on legal decisionmaking in contexts more mundane than, for example, criminal sentencing would therefore appear warranted (Teichman and Zamir, 2014, 693). Moreover, behavioural findings would benefit from territorial diversification, including legal systems and cultures in continental Europe.

The present article aims to contribute to behavioural legal research by developing a novel hypothesis combining the potency of framing and legal attachment to (perceived) objectivity and impartiality. The experimental setup constructed for the purpose of testing this hypothesis engaged law students in 'traditional' - in continental European terms - legal analysis consisting of the application of doctrinal rules and principles to two factual scenarios in order to make a motivated choice between two legal options. Uniquely in the experimental legal literature, European Union law was used as the substantive area of law for the experiment. The experiment revealed that legal argumentation treated with a 'political' frame made law students $12 \%$ to $24 \%$ more likely - varying with legal indeterminacy of the scenario - to select the untreated, 'apolitical' legal option. This conclusion is paradoxical: in trying to be (or appear) impartial, lawyers become influenced by legally irrelevant information.

\section{The Apolitical Hypothesis}

Legal systems and cultures rest on various myths and normative aspirations (Scheingold, 2004; Scheb and Lyons, 2000; Baird and Gangl, 2006; Gibson and Caldeira, 2011). Among the most important ones, at least in the European legal space, are objectivity and impartiality. By these two closely related concepts I refer to the law being, first, dissociated in legal practice from the beliefs and (often political) preferences surrounding its legislative or judicial origins and, second, perceived as neutral (unbiased), not favouring any particular 
individual subject or group. ${ }^{1}$ These notions are as much an implicit part of the broader legal environment or culture as they are part of the legal systems to which the culture pertains. The concepts of objectivity and impartiality espoused here thus go beyond the substantive rules found all across the European legal space, such as the well-established requirement in Article 6 of the European Convention on Human Rights for tribunals to be 'independent and impartial'. Nevertheless, these rules, along with broader principles such as the 'rule of law', ${ }^{2}$ fortify the importance of objectivity and impartiality in legal orders and cultures.

The legal-positivist paradigm, dominant in most of the world and certainly in Europe, nourishes and requires the objective and impartial image of the law (Gillman, 2001). Legal positivism is premised on the separation of law and morality - a law derives its binding nature from being created pursuant to a pre-determined procedure, regardless of whether it might be ordinarily perceived as biased or unfair. Moreover, the language of law is prima facie neutral, drafted so as not to convey any overt sentiment or belief. Its oftassociated characteristics are 'stiffness, formality, technical terminology' (Varo and Hughes, 2002; Berukstiene, 2016). Although judicial writing may be slightly less constrained than the language of statutes, in the European civil law context judges typically write in less subjectified style than their common law counterparts (de S.-O.-L'E. Lasser, 2004) and remain firmly wedded to impartial language (Breda, 2017). ${ }^{3}$ The aspiration in most civil law systems is to present the judge as merely the 'mouth of the law' (Montesquieu, 1748). Given the extent of endogeneity between lawyers' pleadings and judicial decisions, it would be indeed surprising if lawyers and other legal professionals did not copy the objective and impartial language and overall presentation style of laws and judgments. Personification of judges and lawyers - as inherent in for example quality rankings of legal services - are met with criticism from practitioners, fearing that the purity of the legal process might be tainted. ${ }^{4}$ France's recent decision to criminalize judicial analytics ${ }^{5}$ is a stark example of the lengths to which actors might be willing to go in order to safeguard this legal mythology.

Traditional European law schools, where among others the empiricist ethos is in scant supply, perpetuate the legal system and culture through both doctrinal teaching and research (Dyevre et al., 2019; Siems and Síthigh, 2012). Emphasis is placed on the legalpositivist hierarchy of rules with courts playing the role of independent interpreters who decide - or uphold the appearance of deciding - on the basis of legal rules alone (Hart, 1994, 141; Mackie, 1977, 7). Most European law students are never exposed to behavioural research on legal decision-making. On the contrary, deference to legal authority is imparted by teaching law in a formalist and doctrinal manner. Even students in the US have been

\footnotetext{
${ }^{1}$ These notions are related to the 'myth of legality' elaborated elsewhere (Casey, 1974; Scheb and Lyons, 2000; Baird, 2001), as well as the ideological implications of legalism (Shklar, 1964; Scheingold, 2004).

${ }^{2}$ The rule of law is, among others, listed in Article 2 of the Treaty on European Union. That serious value can be attached to this principle by various actors is illustrated by the ongoing legal and political contestation between the European Commission and EU Member States (notably Poland and Hungary).

${ }^{3}$ de S.-O.-L'E. Lasser 2004, 62 talks about a bifurcation in the French Civil Law system between an official formalist discourse - the one of importance for the apolitical hypothesis - and an 'unofficial social responsiveness debate', and contrasts this with the way American judicial opinions combine formalist and policy discourses.

${ }^{4}$ The idea of a 'pure' law has a strong pedigree in the legal-positivist imagination (Kelsen, 1934).

${ }^{5}$ See Article 33 of Law No 2019-222 of 23 March 2019 on programming period 2018-2022 and justice reform.
} 
shown to have great attachment to the legalistic mindset (Baird and Gangl, 2006; Scheingold, 2004) and there is no reason to think Europeans are less legalistic (the opposite, if anything).

Assuming that legal systems and cultures, in particular legal education, foster attachment (or at least the appearance thereof) to objectivity and impartiality in the community of legal practitioners, how do lawyers react to non-conforming information? What if an actor deviates from the objectivity and impartiality criteria in their legal argumentation? These questions are at the heart of the present investigation. It is hypothesized that lawyers react negatively if faced with non-compliant information. More specifically, the hypothesis developed here uses the word 'political' which transmits the idea of partisanship. To say that an actor advances a certain legal position 'for political reasons' violates both objectivity and impartiality as defined above in that the (selfish) interest of the actor is revealed, as well as their instrumentalization of the law for achieving partisan gain. The legal argument is not presented - as the prevailing discourse would demand - as objectively and impartially reflecting the law. The median lawyer should be annoyed by this, because she is, according to this hypothesis, apolitical in her legal work.

The 'apolitical hypothesis' rests primarily on two important behavioural findings. The 'political' treatment is experimentally applied through the medium of framing (Tversky and Kahneman, 1981, 1986; Keren, 2011). Labelling an argument 'political' or 'politically motivated' is hypothesized to constitute a negative frame that will sharply reduce the attractiveness of the associated legal option. In the typology of Levin et al. (1998), the political frame belongs in the family of 'attribute framing, which affects the evaluation of object or event characteristics'. Attribute framing differs slightly from classical prospect theory applications ${ }^{6}$ - which Levin et al. (1998) call 'risky choice framing' - in that evaluation of one option also provides information about the other option which is not the case in risky choice framing. The apolitical hypothesis engages two aspects, termed external and internal by Jullien (2016), of framing: the presentation of a choice as political and lawyers' own (negative) perception of the frame.

Underpinning the study of framing effects is the need for the choices presented to be equivalent and thus unexplainable other than by reference to decision-making bias. Departing from classical framing experiments, the equivalence of interest here is not logical but legal and the options are embedded in a legal context (Sher and McKenzie, 2006; Bless et al., 1998). In the realm of the law, framing experiments should therefore convey legally irrelevant information to leave the balance of doctrinal analysis undisturbed. ${ }^{7}$ Several studies on the effects of legally irrelevant information have shown that jurors' as well as judges' decision-making can be influenced in this manner (Greene and Dodge, 1995; Wissler and Saks, 1985; Tanford and Cox, 1988; Eisenberg and Hans, 2009). Such information appears

\footnotetext{
${ }^{6}$ According to prospect theory, the underlying decision-making process proceeds in two steps: in the first phase, the subject scans the decision problem, including its framing, which is 'controlled by the manner in which the choice problem is presented as well as by norms, habits, and expectancies'. Second, the framed choices are evaluated, and the most valuable option selected (Tversky and Kahneman, 1986, 257).

${ }^{7}$ The emphasis on legal equivalence is important here. The hypothesis tries to tap into pitfalls in paradigmatic legal behaviour rather than claiming that the political treatment does not affect the subject in some other way. The argument tackles the assumed ability of lawyers to decide purely on the basis of the law.
} 
hard to shake off even when its irrelevance is emphasized, as in judicial admonitions of inadmissible evidence (Steblay et al., 2006; Wistrich et al., 2005). In the present context the legally irrelevant information imparted is more subtle, posing the question whether an effect can be detected in a vastly different and less ostensible setting.

The hypothesized impact of a political frame on lawyers' decision-making is potentially reinforced by group membership. As already mentioned, European lawyers are educated together in environments which cultivate neutrality, objectivity and attachment to doctrinalism. The idea of 'motivated cognition' anticipates subjects to unconsciously resist or discount information that does not conform to commonly held beliefs within their group (Kahan, 2013; Cohen, 2003). Arguably, we would expect motivated reasoning to play a greater role when subjects' reasoning could additionally also signal in-group loyalty to other members (or opposing groups) but, because test answers are only seen by the investigator, the scope for signalling is very limited. Nonetheless, in the context of the apolitical hypothesis, motivated cognition offers an explanation that is compatible with the impact of framing on legal decision-making.

The hypotheses, including an explicit null, tested in the randomized experiment reported below can be summarized as following:

$H_{0}$ : Overt indication of political motivation does not reduce the relative value of a legal choice to which the political frame is attached at statistically significant levels.

$H_{1}$ : Overt indication of political motivation reduces the relative value of a legal choice to which the political frame is attached at statistically significant levels.

\section{Experimental Setup}

The experiment designed to test the apolitical hypothesis took place in a class concerning European Union (EU) law at a major and traditional Belgian law school in November 2018 with 88 students. $^{8}$ The class was an ordinary part of a course consisting of seminars on selected issues in EU law. Although students are able to choose at the beginning of the semester from among several seminar tracks (covering different areas of law), no further selection into the experiment occurred. Active participation in classes was mandatory and included preparing in advance. As each class of the course was graded, students had an incentive to do well in the experiment which was labelled an in-class assignment. ${ }^{9}$

A particular issue of EU law to which the class was devoted - the choice of legal basis of EU legislation - was selected as the substantive area for the experiment. Two factual scenarios with differing degrees of legal ambiguity were prepared. The vignettes had to be carefully drafted to approximate real-world legal problems and induce the cognitive processes associated with legal reasoning and decision-making. This included the need for legal choices to be legally motivated, as is customary in practice, despite the measurement instrument being only concerned with the binary choice the law students were asked to make from among two pre-specified options.

\footnotetext{
${ }^{8}$ The law school produces the bulk of the country's lawyers and judges, which should add to the experiment's external validity.

${ }^{9}$ Four sessions with 22 students on average were run. Their median age was 22 and the majority of them were female $(68 \%)$.
} 


\subsection{Legal basis of EU legislation}

Legal bases are in the parlance of EU law provisions of a legal text (typically one of the EU Treaties) which empower the EU or one of its institutions to make law. A legal basis must be chosen from a more or less diverse menu of options, depending on the subject area of the envisaged law. The first mover is normally the European Commission which selects the legal basis of the legislative proposal. The European Parliament, but more likely the Council of the EU, can change the legal basis with sufficient political support. The contestation of the legal basis of a given EU law is a regular feature of inter-institutional EU politics since the late 1980s.

The leading work on this issue has clearly identified strategic (political) motivations underlying actors' decisions about which legal basis should be chosen when promulgating EU law (Jupille, 2004). The reason for actors' political interest in the choice of legal basis has to do with the fact that this choice also determines the procedure - and the relative influence of each EU institution - to be followed in the law-making process. ${ }^{10} \mathrm{As}$ a result, the choice of legal basis of EU legislation offers a potentially fertile ground to observe the impact of the apolitical hypothesis, even though we are not interested in the effects of political motivation per se but rather the frame they engender.

Contrary to the findings of political scientists, many EU lawyers and legal scholars believe that legal basis choices follow from the law and, in particular, the doctrine of the European Court of Justice (ECJ) (Klamert, 2010; Barents, 1993). ${ }^{11}$ The doctrine of the ECJ requires, in essence, the choice of that legal basis which most closely coheres with the substantive area of the proposed legislation. The relevant rule as found in the case law, and as affirmed in over 80 other judgments, has the following formulation:

in the context of the organization of the powers of the Community the choice of the legal basis for a measure may not depend simply on an institution's conviction as to the objective pursued but must be based on objective factors which are amenable to judicial review [...]. Those factors include in particular the aim and content of the measure. ${ }^{12}$

Many laws do not, however, map neatly on merely a single legal basis, thus creating ambiguity as to which legal basis is legally 'correct'. Nonetheless, law students are taught to apply the legalistic model of reasoning in order to identify the legally appropriate provision of EU law. In the legalistic/doctrinal model, political motivation of legal basis choices is legally irrelevant.

\subsection{Scenarios and ambiguity}

The subjects were asked to choose and justify the 'appropriate' legal basis of two trimmeddown real-world EU legislative acts called 'draft legislation A' and 'draft legislation B'.

\footnotetext{
${ }^{10}$ Typical bones of contention concern the extent to which the European Parliament must be involved in the legislative process and whether the Council adopts the law by unanimity or qualified majority.

${ }^{11}$ Note the incidental support for the theoretical motivation of the apolitical hypothesis in the scholarly work of legal academics on choice of legal basis.

${ }^{12}$ Case C-300/89 Commission v Council (Titanium Dioxide) [1991] ECLI:EU:C:1991:244, para 10.
} 
Legislation A concerned road traffic offences, while legislation B was about value-added tax (VAT).$^{13}$ The two vastly different areas were selected to mitigate potential effects entailed by issue specificity. However, the scenarios of the two laws A and B also intentionally varied from the standpoint of determinacy - the road traffic law was more ambiguous (it had been in fact litigated), while the VAT act had a relatively straightforward and uncontested 'solution'. Students had to choose among two legal basis options in each scenario.

Legislation A was the object of a real judicial dispute in Case C-43/12. The act was originally adopted on the basis of Article 87(2)(a) of the Treaty on the Functioning of the European Union (TFEU) which concerns police cooperation in criminal matters, namely exchange of information. Compared to the alternative advocated by the Commission Article 91(1)(c) TFEU - the choice of Article 87 TFEU had the consequence of giving opt-outs to the UK, Ireland and Denmark and was not part of the European Economic Area (EEA) acquis. In the case before the ECJ, the Commission successfully argued that the more appropriate legal basis was Article 91(1)(c) TFEU which is part of the Title on transport policy. A new law based on Article 91 TFEU was adopted within 12 months of the judgment, as required by the Court. ${ }^{14}$

Legislation A - that is a four page version of Directive 2011/82/EU - was selected because it presented a difficult choice of legal basis, requiring subjects to determine the 'centre of gravity' of the act. ${ }^{15}$ On the basis of the case law, the Directive could be persuasively argued to fall under either legal basis, depending on whether the information exchange or the transport safety dimension was more accentuated. It was hypothesized that in such ambiguous circumstances the choices in the control group should essentially follow a random distribution with the probability of either legal basis being selected amounting to approximately $P=0.5$. The excerpt of Directive 2011/82/EU included in the experimental testing as legislation A was carefully balanced so as not to favour the choice of either legal basis.

Unlike Legislation A, Legislation B was meant to present a more clear-cut choice of legal basis. Directive 2017/2455/EU of 5 December 2017 amending Directive 2006/112/EC and Directive 2009/132/EC as regards certain value added tax obligations for supplies of services and distance sales of goods was chosen as a relatively mundane legislative act. The act was based on Article 113 TFEU and there was no legal challenge to it. Article 114(1) TFEU was artificially introduced as an alternative in the experiment but several doctrinal reasons militated against its use according to the case law: it was a subsidiary ${ }^{16}$ and less specific legal basis than Article $113 \mathrm{TFEU},{ }^{17}$ as VAT represents an instance of indirect taxation explicitly covered under the latter. In addition, paragraph 2 of Article 114 TFEU states that paragraph 1 'shall not apply to fiscal provisions'. Any one of these reasons

\footnotetext{
${ }^{13}$ The real-world sources drawn from were Directive (EU) 2011/82 for legislation A and Directive (EU) $2017 / 2455$ for legislation B.

${ }^{14}$ Directive (EU) 2015/413 of the European Parliament and of the Council of 11 March 2015 facilitating cross-border exchange of information on road-safety-related traffic offences [2015] OJ L68/9.

${ }^{15}$ The concept of centre of gravity entails determining which substantive aspect of a law is the most prominent, and thus decisive for the choice of legal basis.

${ }^{16}$ The provision starts with 'Save where otherwise provided in the Treaties, the following provisions shall apply $[\ldots]$ '.

${ }^{17}$ As regards more general legal bases, such as Article 114(1) TFEU, being subsidiary to more specific powers, see among others Case C-131/87 Commission of the European Communities $v$ Council of the European Communities [1989] ECLI:EU:C:1989:581 and Case C-22/96 European Parliament $v$ Council of the European Union [1998] ECLI:EU:C:1998:258.
} 
would have been sufficient in itself to induce subjects to overwhelmingly prefer Article 113 TFEU as legal basis. From a legal perspective, therefore, legislation B was much more straightforward than legislation A.

In the case of legislation $B$ it was more difficult to define a prior expected probability of either outcome occurring but a threshold of $P_{114}=0.15$ was selected for working purposes. This probability represents an approximate quantification of the expectation that legislation B should have a clear legal basis, although any number below 0.30 would be arguable. ${ }^{18}$ Ultimately, the treatment effect must in any case be evaluated against the observed posterior probabilities in the control group, because only these will reflect the actual performance of the design, in particular the envisaged difference in ambiguity between the two scenarios (see Appendix). In the absence of similar studies, the size of the anticipated treatment effect was unknown, thus precluding an ex ante power analysis.

The difference in the level of ambiguity of the two laws was introduced to test the limits of the framing effect: nudging subjects towards the 'apolitical' legal basis was predicted to be easier when the legislation would be ambiguous (A) compared to a file (B) where all the legal considerations point towards choosing the 'politicized' legal basis. Legislation $B$ was thus expected to constitute a hard case for the hypothesized effect of framing: could subjects be influenced to such a degree that they would make a choice against the bulk of legal arguments? Besides, differing ambiguity is a feature of real-world law-making and a key explanatory variable in the theory of Jupille (2004).

\subsection{Preparation and treatment}

Subjects were given a week to prepare for the class and were provided with materials which consisted almost exclusively of the ECJ doctrine, indicating that the latter would be crucial to solving legal problems in the domain of legal basis. The students had some prior knowledge of EU law, varying individually and had already studied at the law school for over three years at the time of the experiment.

In class students were given approximately 40 minutes to complete the assignment, which asked for the selection of the appropriate legal basis for each scenario (from two given choices) and a written justification specifying the legal arguments supporting their choice. Subjects were ordered to put away all their electronic devices to recreate standard university testing conditions. Prior to receiving the test, each student received a copy of 'draft legislation A', 'draft legislation B' and a copy of selected Treaty provisions which were necessary to 'solve' the assignment. Students were also allowed to bring the reading materials assigned a week before (excerpts of doctrine), including any hand-written annotations and notes made during preparation. Students were informed that there were different test versions and observed in class to prevent copying of answers. ${ }^{19}$ No apparent issues or

\footnotetext{
${ }^{18}$ Specifying prior expectations as precisely as possible - even in the absence of much information - aids research transparency. The prior is of lesser importance in this case due to the novelty of the experimental design but setting measurable standards arguably fosters good research practices. The posterior distributions from this experiment in turn lay the foundation for priors in future work in this area.

${ }^{19}$ The experiment was not designed to address the objection put forward by Druckman (2001) that framing effects are diminished outside laboratory conditions where subjects can exchange and have access to credible information.
} 
disruptions arose during the conduct of the experiment.

The treatment consisted of a legally irrelevant political frame attached to one of the legal bases in each scenario. Each student was part of the treatment group for one scenario and control for the other (to prevent treatment detection). This within-subject design was added to also economize on resources while maximizing the number of responses. The treatments were assigned with full randomization, including random order of tasks in order to eliminate possible undesirable distortion by the within-subject component of the experiment. Altogether four test versions were created to ensure that every subject had the same chance of (1) being treated for scenario A and thus not for B, and vice versa; and (2) receiving a sheet with scenario $\mathrm{A}$ as the first task and $\mathrm{B}$ as second, and vice versa.

Testing on two scenarios called for the creation of four vignettes: control A, treatment A, control B and treatment B. The insertion of the treatment required additional contextual information to make the assignment appear credible. The goal was to approximate as much as possible standard legal classroom conditions. The control vignettes were worded thus:

Read the attached excerpt of draft legislation "A" and assess it in light of your knowledge of the legal basis doctrine. Choose the appropriate legal basis and motivate your choice.

Read the attached excerpt of draft legislation "B" and assess it in light of your knowledge of the legal basis doctrine. Choose the appropriate legal basis and motivate your choice.

The treatment vignettes were worded in the following way:

Read the attached excerpt of draft legislation "A". The European Commission proposed it with Article 91(1)(c) TFEU as legal basis but some Member States would prefer for political reasons Article 87(2)(a) TFEU, as this legal basis would give them an opt-out from the legislation. Assess draft legislation "A" in light of your knowledge of the legal basis doctrine. Choose the appropriate legal basis and motivate your choice.

Read the attached excerpt of draft legislation "B". The Council wishes to use Article 113 TFEU as legal basis for political reasons, as this provision requires unanimous agreement of Member States. On the contrary, the European Commission is of the opinion that Article 114(1) TFEU is the right legal basis given that the legislation relates to the services and goods in the internal market. Assess draft legislation "B" in light of your knowledge of the legal basis doctrine. Choose the appropriate legal basis and motivate your choice.

We can therefore see that in scenario A the framing treatment related to Article 87 TFEU and in scenario B to Article 113 TFEU. The hypothesis predicts that the frame devalues these legal options. As only one alternative is possible, we can also express the relative decline in attractiveness of Article 87 and Article 113 in terms of an increasing relative preference for Articles 91 and 114(1) respectively. In the statistical evaluation of the experiment, and in light of the binary nature of the outcome variable, a subject choosing 
Article 91 in scenario A and Article 114(1) in scenario B is counted as a 'success' (which it would be under treatment conditions based on the alternative hypothesis), denoted $x$.

All vignettes were followed by the sentence: 'The legal basis of draft legislation X should be:' and the stipulation of the two options available for each scenario. Immediately below the assignment stated: 'Motivate thoroughly your choice of legal basis'. Table 1 summarizes the main features of the design.

\begin{tabular}{lllllc}
\hline \hline Scenario & Subject area & Ambiguity & Choice & Treatment & Treated option \\
\hline A & road traffic & High & $91 \mathrm{v} 87$ & political motivation & 87 \\
\hline B & VAT & Low & 113 v 114 & political motivation & 113 \\
\hline
\end{tabular}

Table 1: Main features of the experimental design.

\section{Results and Discussion}

Table 2 reports the frequencies of subjects' legal choices for both scenarios. In the aggregate, 15 more subjects chose the 'apolitical' legal basis in the treatment group than the control group.

\begin{tabular}{lcccc}
\hline \hline Scenario & $n_{\text {control }}$ & $n_{\text {treatment }}$ & $x_{\text {control }}$ & $x_{\text {treatment }}$ \\
\hline $\mathrm{A}$ & 45 & 42 & 18 & 22 \\
\hline $\mathrm{B}$ & 42 & 45 & 2 & 13 \\
\hline $\mathrm{A}+\mathrm{B}$ & 87 & 87 & 20 & 35 \\
\hline
\end{tabular}

Table 2: $n$ denotes the number of responses with missing values (2) omitted, $x$ the number of 'successes' (choice of Article 91 TFEU in scenario A and Article 114(1) TFEU in scenario B). 8 responses ( 5 control, 3 treatment) in scenario A chose a 'dual' legal basis, despite the explicit instruction to choose one or the other. The doctrine supported such an interpretation to a large extent (other than for very specific information not given in the scenario), showing the eagerness of the law students to observe the putative demands of the law (doctrine) at the expense of disobeying a test instruction. In order not to lower the threshold for finding an effect, these 8 responses were coded as Article 87 TFEU (failure under the treatment condition). Dropping these observations from the analysis has virtually no effect on the results.

With the experimentally generated data we can construct loglikelihood functions to visualize the differences in the proportion of successes for each group. ${ }^{20}$ The loglikehood function takes the sample size $n$ and the number of successes $x$ to derive the unknown parameter $\theta$. What we are particularly interested in is the value of $\theta$ at which each function is maximized. The maximum (log)likelihood for a binomial distribution with iid random variables is simply $\hat{\theta}=x / n .^{21}$

\footnotetext{
${ }^{20}$ The logarithmic transformation of the likelihood function $L(\pi \mid x)=\frac{n !}{(n-x) ! x !} \pi^{x}(1-\pi)^{n-x}$ is done merely out of computational convenience.

${ }^{21}$ The $\theta$ parameter of the control likelihood functions can be compared to the working prior expected probabilities attached to each outcome under different ambiguity conditions of the two scenarios. Only the observed (posterior) $\theta$ of the control functions is important for the analysis of the results but the Appendix
} 


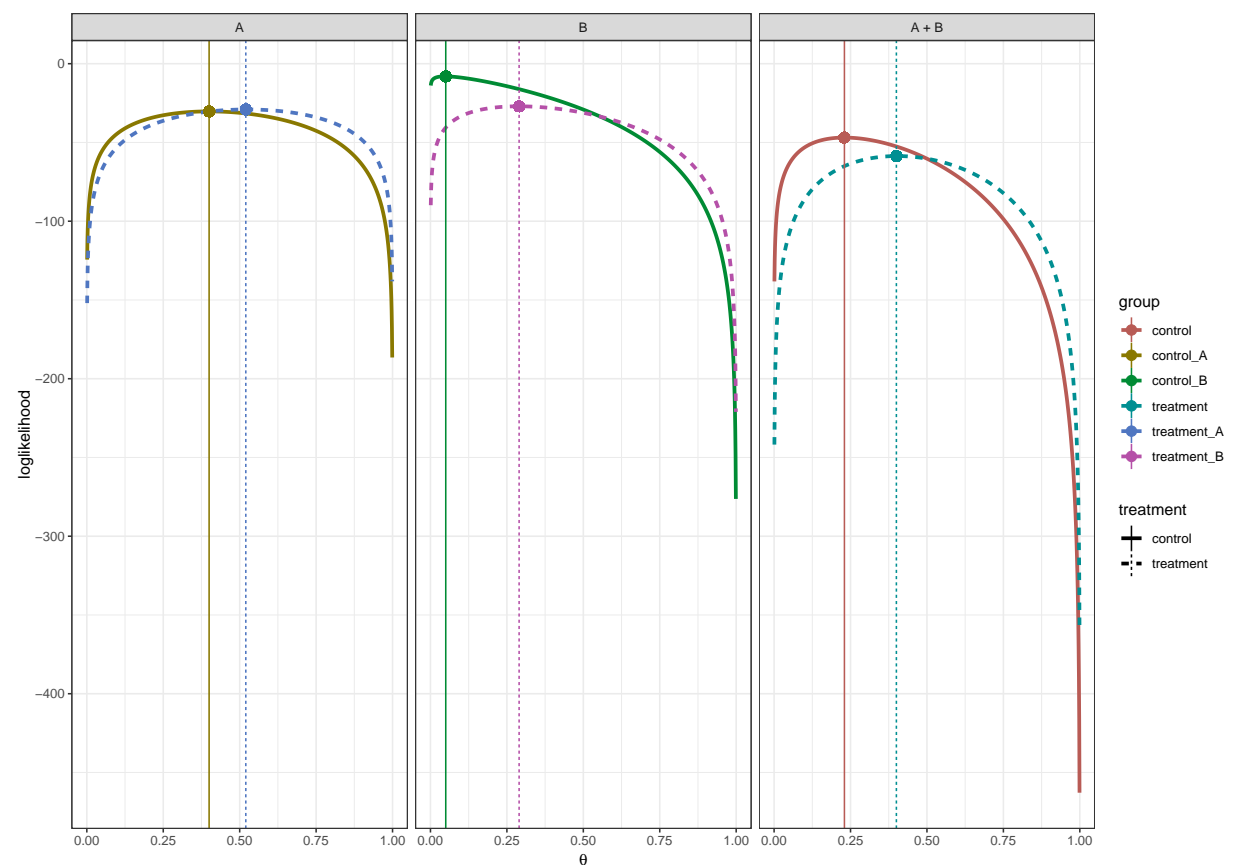

Figure 1: Loglikehood functions showing parameter $\theta$ given successes $x$ and sample size $n$ under each experimental condition. The point on each function denotes the maximum likelihood.

The $\theta$ difference between the control and treatment function for each scenario represents the effect size of the treatment. We can see strong evidence for the alternative hypothesis, because in all scenarios the maximum likelihood point of the treatment function lies to the right of the maximum likelihood of the control function. In other words, both at the disaggregated and aggregated level the subjects were more likely (positive effect) to select the 'apolitical' legal basis under treatment conditions. The exact effect size can be calculated as the loglikelihood ratio

$$
L R=\frac{\log L(\theta \mid x)_{\text {treatment }}}{\log L(\theta \mid x)_{\text {control }}}
$$

or, because the $\theta$ parameter captures a proportion, as Cohen's h

$$
h=\phi_{\text {treatment }}-\phi_{\text {control }}
$$

where $\phi$ is the arcsine transformation $2 \arcsin \sqrt{p}$ of proportion $p .^{22}$ Table 3 summarizes the effect sizes for each scenario.

discusses the discrepancy between expected and observed probabilities as a measure of performance of the experimental design.

${ }^{22}$ In this equation $\mathrm{h}$ is directed and a positive sign shows the positive effect of the treatment. 


\begin{tabular}{lccc}
\hline \hline Scenario & $\Delta \hat{\theta}$ & $L R$ & Cohen's h \\
\hline $\mathrm{A}$ & 0.12 & 0.96 & 0.24 \\
\hline $\mathrm{B}$ & 0.24 & 3.37 & 0.69 \\
\hline $\mathrm{A}+\mathrm{B}$ & 0.17 & 1.25 & 0.37 \\
\hline
\end{tabular}

Table 3: $\Delta \hat{\theta}$ and effect sizes expressed as the loglikelihood ratio (LR) and Cohen's $\mathrm{h}$ for each scenario.

Before we can interpret the effect sizes we need to check whether the results are statistically significant at the conventional $\alpha<0.05$. Given the discrete nature of the observations, we can use the parametric Z-statistic or a cohort of non-parametric alternatives to test whether the treatment group chose significantly more 'successes' than the control group. ${ }^{23}$ All tests are one-sided because our alternative hypothesis stipulates a positive treatment effect; a negative effect must be considered as not rejecting the null hypothesis. Testing under the null hypothesis essentially asks whether there is a non-random - allowing for a long-run Type I error rate of $5 \%$ - difference between the control and the treatment sample. Table 4 reports the $p$-values of all the relevant statistical significance tests.

\begin{tabular}{lccccc}
\hline \hline Scenario & Z-statistic & Fisher's test & Barnard's test & Chi-squared test & G-test \\
\hline $\mathrm{A}$ & 1.591 & 0.173 & 0.138 & 0.346 & 0.251 \\
\hline $\mathrm{B}$ & $5.166^{*}$ & $0.003^{*}$ & $0.002^{*}$ & $0.007^{*}$ & $0.002^{*}$ \\
\hline $\mathrm{A}+\mathrm{B}$ & $3.442^{*}$ & $0.011^{*}$ & $0.008^{*}$ & $0.022^{*}$ & $0.015^{*}$ \\
\hline
\end{tabular}

Table 4: Results of null hypothesis testing of whether the treatment group has chosen a significantly higher number of 'successes' than the control group. The null hypothesis that there is no significant difference is rejected at $\alpha<0.05$. Results rejecting the null are marked with an asterisk. All reported numbers are $p$-values except for the Z-statistic: a one-tailed Z-statistic is statistically significant at $\alpha<0.05$ if $z>1.64$ and $h>0$. The chisquared test calculation takes into account Yates' continuity correction, which constitutes the most conservative approach. The G-test is computed with William's correction which is appropriately less conservative given the absence of zeros in the data. Without corrections, chi-squared and G-test return nearly identical values. In any case, Fisher's and Barnard's exact tests give the most precise $p$-values for this dataset.

All test statistics tell the same story: the between-group difference is statistically significant in a theoretically relevant way for the aggregate data and scenario B but not scenario A. The likelihood of Type I error is consistently smallest for scenario B and largest for scenario A. The $p$-values therefore mirror the ordering of the effect sizes for the different experimental conditions: $h_{B}>h_{A B}>h_{A}$. While formally we must conclude that data for scenario A does not demonstrate a statistically significant between-group difference, $h=0.24$ would represent a 'small' effect size in the standardized vocabulary of Cohen Co-

\footnotetext{
${ }^{23}$ Given doubts about the underlying normality assumption of the Z-statistic for our data (notably scenario B), non-parametric tests add robustness to the analysis. These include Fisher's exact probability test, Barnard's test, Pearson's chi-squared test and a G-test. They should all yield similar $p-$ values when testing for between-group difference. The difference between Fisher's and Barnard's test is that Fisher's test uses fixed margins, while Barnard's test allows for random margins.
} 
hen (1988). In light of the significant and larger effects found in aggregate and scenario B data, it seems plausible that the hypothesized apolitical effect does exist but the design of scenario A was not sufficiently sensitive (unlike scenario B) to detect the effect.

Although an ex post power analysis cannot be used for inferential purposes (Hoenig and Heisey, 2001), it is useful for future studies to reflect on the sensitiveness of the present experimental design. While the aggregate power of the experiment was 0.79 - the usually recommended level being $80 \%$ - scenario A had merely 0.30 power, which follows from the smaller effect size caused by greater stochasticity in the legal choice. In contrast, the large effect size detected in scenario B translates into 0.94 power given $n=87$. Assuming $h_{A}=0.24$ constituted the true effect size for a degree of legal ambiguity such as in scenario A, a sample of $n=212$ would be necessary to find a statistically significant result at $\alpha=0.05$ (Type I error rate or probability of false positives) and $\beta=0.20$ (Type II error rate or probability of false negatives).

Thinking about sample sizes and variable ambiguity - which translates into different baseline probabilities of choosing one or the other legal option ${ }^{24}$ - furthermore illuminates why the theoretically 'hard' case (scenario B) proved counterintuitively more sensitive to detecting an effect. Consider a design similar to the one presented in this paper but (for simplicity) with two groups of 50 subjects each. Varying ambiguity from low (scenario B) to high (scenario A) requires a larger number of subjects selecting the hypothesis-confirming legal option if we are to find a statistically significant treatment effect using Fisher's exact test. ${ }^{25}$ As visualized in Figure 2, in a very low ambiguity context (akin to scenario B), only 10 subjects need to respond to treatment as hypothesized in order to achieve statistical significance. Conversely, given the same number of participants, high ambiguity would require 36 subjects to conform to treatment. This means that the same significance level 'costs' three more conforming responses in the treatment group compared to the control baseline (at $N=50$ ), purely due to the higher ambiguity. ${ }^{26}$

\footnotetext{
${ }^{24}$ The level of ambiguity is in statistical terms a hyperparameter defining the underlying binomial distribution of outcomes in the control group.

${ }^{25} P$ - values in Fisher's exact test are computed using factorials as $p=\frac{(a+b) !(c+d) !(a+c) !(b+d) !}{a ! b ! c ! d ! N !}$ where $\{a, b, c, d\}$ are the four quadrants of a $2 \times 2$ contingency matrix of individual frequencies and $N$ is the total number of observations.

${ }^{26}$ At $5 \%$ ambiguity, 2 participants in the control group choose the unlikely option, while at $50 \%$ ambiguity 25 choose each. So $10-2=8 ; 36-25=11 ; 11-8=3$.
} 


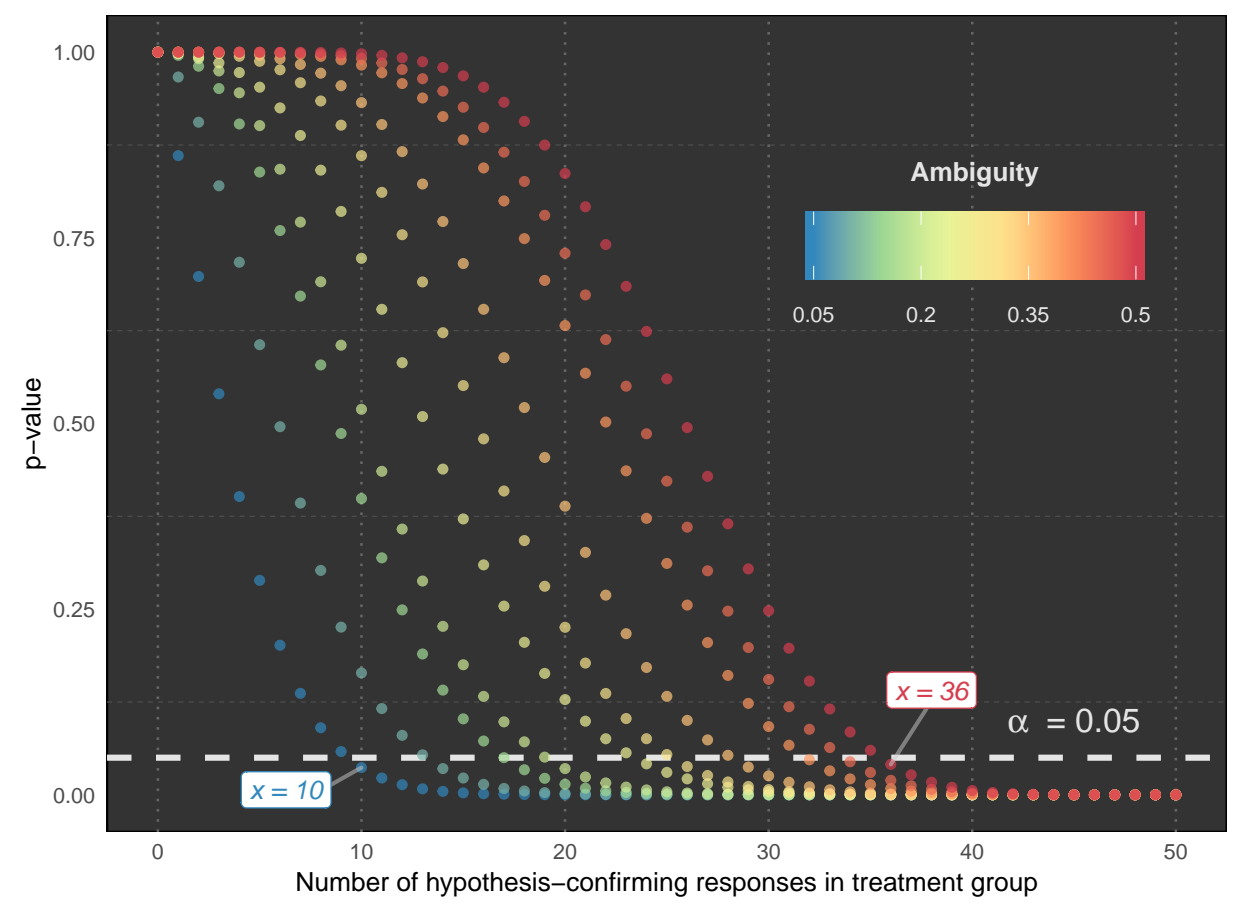

Figure 2: Effect of ambiguity on $p$-values in a design with 50 subjects per group. As ambiguity increases (value approaches 0.5 ), the number of hypothesis-confirming responses in the treatment group must increase disproportionately in order to find a significant effect at the 5\% level. $P$-values are calculated using Fisher's exact test on 10000 randomly drawn samples from probability mass functions of ten binomial distributions with 'true' ambiguity varying from 0.05 (low) to 0.50 (high).

The statistical implication of the ambiguity effect is that sample sizes should be adjusted in experimental designs if groups facing different ambiguity are to be compared. As this impact of varying ambiguity was not foreseen in the preparatory stage, the best we can do is to caution future research on this point and take it into account in the interpretation of the study. Ambiguity therefore to some extent explains the non-significant result for scenario A, its lower power, as well as why the political effect in scenario B - theoretically considered the 'hard' case - was paradoxically 'easier' to establish.

All in all, the most important finding from the theoretical perspective is the more than medium-sized and clearly statistically significant effect identified under scenario B $(h=0.69, p-$ value $<0.005)$. This scenario demonstrated that political treatment can make lawyers turn away from even the most unambiguously clear answers to legal questions. Although the absence of significance in scenario A raises questions which warrant further investigation, the case for the apolitical hypothesis can be considered plausible. The higher level of ambiguity in scenario A has, contrary to expectations, proven to raise the threshold for finding a significant effect. Still, even under scenario A we observed treated subjects select the predicted legal basis more often than the control group. 


\section{Conclusion}

Although the general thrust of behavioural scholarship undermines the relative importance of rules in legal decision-making, laws, their interpretation and application remain the core business of legal practice. The experiment reported in this paper demonstrated the interaction between a behavioural insight - the framing effect - and legalistic rule application, including the impact of varying ambiguity. Framing, in its novel political guise, has been shown to be sufficiently pervasive to significantly influence even a relatively mundane legal decision-making process taking place - as the bulk of legal work does - in writing and outside courtrooms. Next to framing, the results provide further support for the more general thesis that lawyers can struggle to discard legally irrelevant information. In addition, the experimental design extended behavioural legal scholarship into a new doctrinal domain, namely that of European Union law.

Further studies could gauge where the limits of the apolitical hypothesis lay. Legal knowledge and self-confidence might boost lawyers' resistance to politically treated information, even though some existing studies have shown little mitigating influence of knowledge (Rhee, 1997; Druckman and Nelson, 2003; de Vreese, 2004). Alternatively, legal practitioners in areas where political interests are frequently laid bare - such as constitutional law (Kahan, 2011) - might find information presented as political or politically motivated less irritable. The present study provides the groundwork for further experimenting with political and other frames challenging legal professional values. In particular, the observed effect sizes, power considerations and impact of legal ambiguity can inform and improve future experimental designs. 


\section{References}

Baird, V. A.

2001. Building institutional legitimacy: The role of procedural justice. Political Research Quarterly, 54:333-354.

Baird, V. A. and A. Gangl

2006. Shattering the myth of legality: The impact of the media's framing of supreme court procedures on perceptions of fairness. Political Psychology, 27:597-614.

Barents, R.

1993. The internal market unlimited: Some observations on the legal basis of community legislation. Common Market Law Review, 30:85-109.

Berukstiene, D.

2016. Legal discourse reconsidered: Genres of legal texts. Comparative Legilinguistics, 28:89-117.

Bless, H., T. Betsch, and A. Franzen

1998. Framing the framing effect: the impact of context cueson solutions to the 'asian disease' problem. European Journal of Social Psychology, 28:287-291.

Breda, V.

2017. The grammar of bias: Judicial impartiality in european legal systems. International Journal for the Semiotics of Law, 30:245-260.

Casey, G.

1974. The supreme court and myth: An empirical investigation. Law and Society Review, 8:385-419.

Cohen, G. L.

2003. Party over policy: The dominating impact of group influence on political beliefs. Journal of Personality and Social Psychology, 85:808-822.

Cohen, J.

1988. Statistical Power Analysis for the Behavioral Sciences. Lawrence Erlbaum Associates.

de S.-O.-L'E. Lasser, M.

2004. Judicial Deliberations: A Comparative Analysis of Judicial Transparency and Legitimacy. Oxford University Press.

de Vreese, C. H.

2004. The effects of frames in political television news on issueinterpretation and frame salience. Journalism and Mass Communication Quarterly, 81:36-52.

Druckman, J. and K. R. Nelson

2003. Framing and deliberation. American Journal of Political Science, 47:728-744. 
Druckman, J. N.

2001. Using credible advice to overcome framing effects. The Journal of Law, Economics, \& Organization, 17:62-82.

Dyevre, A., W. Wijtvliet, and N. Lampach

2019. The future of european legal scholarship: Empirical jurisprudence. Maastricht Journal of European and Comparative Law.

Eisenberg, T. and V. P. Hans

2009. Taking a stand on taking the stand: The effect of a prior criminal record on the decision to testify and on trial outcomes. Cornell Law Review, 94:1353-1390.

Gibson, J. L. and G. A. Caldeira

2011. Has legal realism damaged the legitimacy of the u.s. supreme court? Law and Society Review, 45:195-219.

Gigerenzer, G. and C. Engel, eds.

2006. Heuristics and the Law. MIT Press.

Gillman, $\mathrm{H}$

2001. What's law got to do with it? judicial behavioralists test the "legal model" of judicial decision making. Law \&S Social Inquiry, 26(2):465-504.

Greene, E. and M. Dodge

1995. The influence of prior record evidence on juror decision-making. Law and Human Behavior, 19:67-78.

Guthrie, C., J. J. Rachlinski, and A. J. Wistrich

2001. Inside the judicial mind. Cornell Law Review, 86:777-830.

Hart, H. L. A.

1994. The Concept of Law, 2 edition. Oxford University Press.

Hoenig, J. M. and D. M. Heisey

2001. The abuse of power: The pervasive fallacy of powercalculations for data analysis. The American Statistician, 55:1-6.

Jolls, C., C. R. Sunstein, and R. Thaler

1998. A behavioral approach to law and economics. Stanford Law Review, 50:1471-1550.

Jullien, D.

2016. All frames created equal are not identical: On the structure of kahneman and tversky's framing effects. Oeconomia, 6:265-291.

Jupille, J.

2004. Procedural Politics: Issues, Influence, and Institutional Choice in the European Union. Cambridge University Press. 
Kahan, D. M.

2011. Neutral principles, motivated cognition, and some problems for constitutional law. Harvard Law Review, 125:1-77.

Kahan, D. M.

2013. Ideology, motivated reasoning, and cognitive reflection. Judgment and Decision Making, 8:407-424.

Kelsen, H.

1934. Pure Theory of Law.

Keren, G., ed.

2011. Perspectives on Framing. Psychology Press.

Klamert, M.

2010. Conflicts of legal basis: no legality and no basis but a bright future under the lisbon treaty? European Law Review, 35:497-515.

Korobkin, R. B. and T. S. Ulen

2000. Law and behavioral science: Removing the rationality assumption from law and economics. California Law Review, 88(4):1051-1144.

Levin, I. P., S. L. Schneider, and G. J. Gaeth 1998. All frames are not created equal: A typology and critical analysis of framing effects. Organizational Behavior and Human Decision Processes, 76:149-188.

Mackie, J.

1977. The third theory of law. Philosophy and Public Affairs, 7:3-16.

Montesquieu

1748. The Spirit of the Laws.

Rachlinski, J. J.

2011. The psychological foundations of behavioral law and economics. University of Illinois Law Review, 2011(5):1675-1696.

Rachlinski, J. J., A. J. Wistrich, and C. Guthrie 2015. Can judges make reliable numeric judgments? distorted damages and skewed sentences. Indiana Law Journal, 90:695-739.

Rhee, J. W.

1997. Strategy and issue frames in election campaign coverage: A socialcognitive account of framing effects. Journal of Communication, 47:26-48.

Robbennolt, J. K.

1999. Anchoring in the courtroom: The effects of caps on punitive damages. Law and Human Behavior, 23:353-373. 
Schauer, F.

2010. Is there a psychology of judging? In The Psychology of Judicial Decision Making, Klein and Mitchell, eds., Pp. 103-120. Oxford University Press.

Scheb, J. M. and W. Lyons

2000. The myth of legality and public evaluation of the supreme court. Social Science Quarterly, 81:928-940.

Scheingold, S. A.

2004. The Politics of Rights: Lawyers, Public Policy, and Political Change, 2 edition. The University of Michigan Press.

Sheffrin, S. M.

2017. Behavioral law and economics is not just a refinement of law and economics. Oeconomia, 7(3):331-352.

Sher, S. and C. R. M. McKenzie

2006. Information leakage from logically equivalent frames. Cognition, 101:467-94.

Shklar, J. N.

1964. Legalism. Harvard University Press.

Siems, M. M. and D. M. Síthigh

2012. Mapping legal research. The Cambridge Law Journal, 71:651-676.

Steblay, N., H. M. Hosch, S. E. Culhane, and A. McWethy

2006. The impact on juror verdicts of judicial instruction to disregard inadmissible evidence: A meta-analysis. Law and Human Behavior, 30:469-492.

Tanford, S. and M. Cox

1988. The effects of impeachment evidence and limiting instructions on individual and group decision making. Law and Human Behavior, 12:477-497.

Teichman, D. and E. Zamir 2014. Judicial decision-making: A behavioral perspective. In The Oxford Handbook of Behavioral Economics and the Law, E. Zamir and D. Teichman, eds., Pp. 664-702. Oxford University Press.

Tversky, A. and D. Kahneman

1974. Judgment under uncertainty: Heuristics and biases. Science, 185(4157):1124-1131.

Tversky, A. and D. Kahneman

1981. The framing of decisions and the psychology of choice. Science, 211:453-458.

Tversky, A. and D. Kahneman

1986. Rational choice and the framing of decisions. Journal of Business, 59:251-279.

Varo, A. E. and B. Hughes

2002. Legal Translation Explained. St. Jerome Publishing. 
Wissler, R. L. and M. J. Saks

1985. On the inefficacy of limiting instructions: When jurors use prior conviction evidence to decide on guilt. Law and Human Behavior, 9:37-48.

Wistrich, A. J., C. Guthrie, and J. J. Rachlinski

2005. Can judges ignore inadmissible information? the difficulty of deliberately disregarding. University of Pennsylvania Law Review, 153:1251-1345. 


\section{A Appendix}

\section{A.1 Design performance}

Due to the novel character of the hypothesis and the original design of the experiment, a degree of uncertainty concerning the intended performance of the conditions was inevitable. The design entailed notably the operationalization of legal ambiguity (indeterminacy) to get a better sense of the limits of the framing effect under investigation. Figure 3 illustrates the difference between intended and observed design performance in the control group. The design predicted a slightly higher number of successes in both scenarios. Importantly, the experiment has borne out the intention to distinguish an indeterminate from a relatively determinate legal problem. Moreover, while the latter scenario was predicted to serve as a litmus test of the political frame, it in fact proved the more sensitive instrument to measure the framing effect; a part of the reason why was that scenario B turned out even more legally determinate in practice than anticipated.

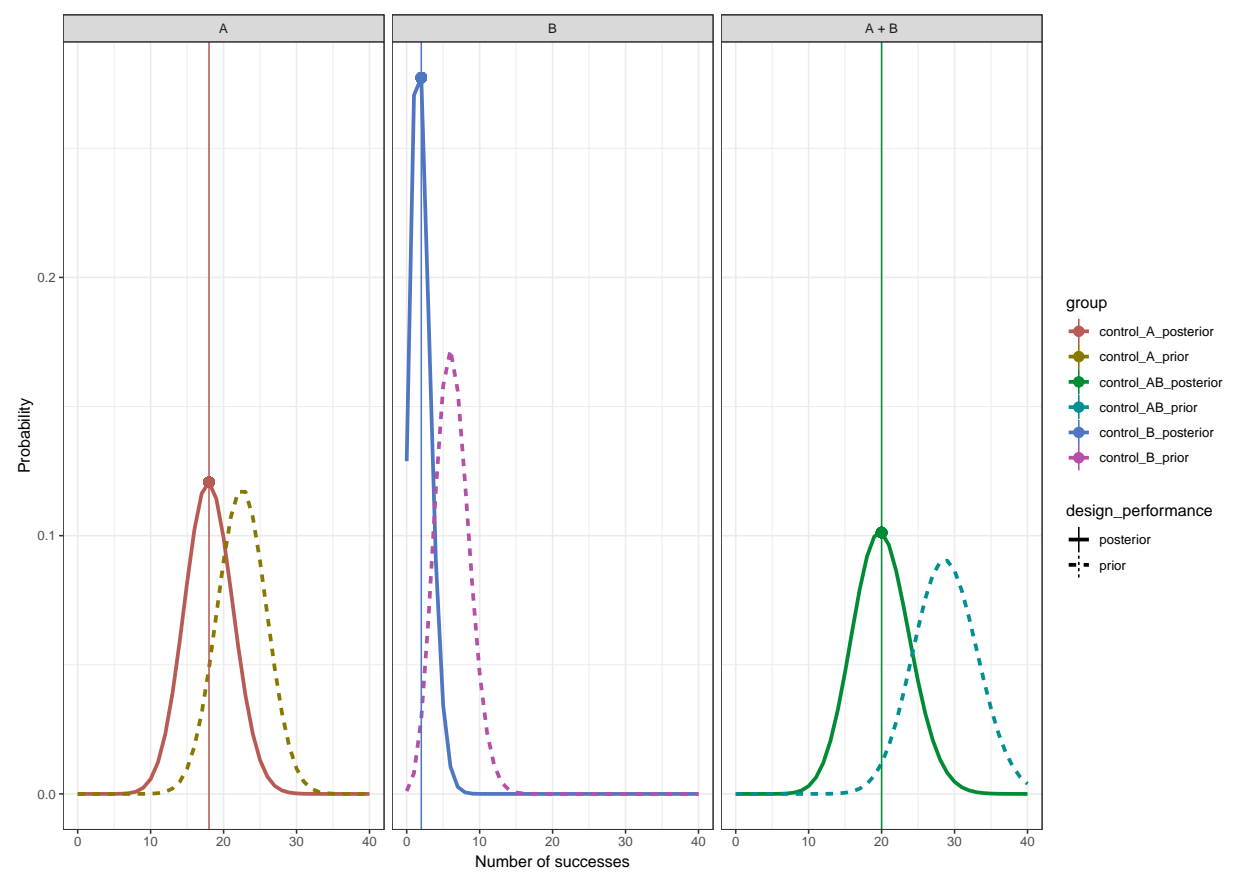

Figure 3: Probability mass functions illustrating the differences between the working prior probability of success in the control group for each scenario and the observed posterior probability of the same. The distributions are given for $n=\{45,42,87\}, x=\{0, \ldots, 40\}$ $p_{\text {prior }}=\{0.50,0.15,0.23\}$ and $p_{\text {posterior }}=\{0.40,0.05,0.23\}$. The prior distribution shows how the experimental design intended to distinguish varying degrees of ambiguity between scenarios A and B. The posterior distribution shows how the design actually performed in practice. On the whole the intention of the design was respected, as there was a significant difference in the probabilities of success in scenarios A and B. Nonetheless, in both scenarios the posterior probability of success was lower than expected. The line form of the probability functions obfuscates the discrete nature of the distributions but is visually more informative. The vertical line marks the actual number of successes in the control group in the experiment, which equals the mode of the probability mass function. 


\section{A.2 Materials}

The following materials were used in the experiment: (1) a textbook-like sheet intended to aid learning about the relevant ECJ doctrine; (2) text of legislation A and B; and (3) texts of relevant Treaty articles. 
This document introduces the concept and doctrine of legal basis (of EU law). Familiarize yourself thoroughly with its contents prior to class where you will be asked to apply your knowledge in a written test. An annotated printout of this document can be used during the test. The remaining time in class will be devoted to discussion.

\section{Introduction}

The concept of legal basis is a ubiquitous and central feature of European Union (EU) law. It has been said to be of 'constitutional significance' on account of making operational one of the foundational principles of EU law, the principle of conferred (or attributed) powers. As the standard formulation goes, the Union only possesses those powers which have been conferred on it by the Member States. The implicit baseline role of the concept of legal basis is to ensure that the principle of conferral is observed in the course of law-making. Ever since the EU had been created, the same formula has accompanied the specification of legal basis in a legal act (which is linked to the duty to state reasons) - it is to be found in the first sentence of the preamble:

“THE EUROPEAN PARLIAMENT AND THE COUNCIL OF THE EUROPEAN UNION,

Having regard to the Treaty establishing the European Community, and in particular Article 47(2) thereof $(\ldots)$

HAVE ADOPTED THIS DIRECTIVE: (...)"

The concept of legal basis can be understood as the idea that any legal act defined in Article 288 of the Treaty on the Functioning of the European Union (TFEU) can only be adopted in accordance with a preexisting provision of EU law conferring the necessary competence for that purpose. Following the nonbinding 'Joint Practical Guide of the European Parliament, the Council and the Commission for persons involved in the drafting of European Union legislation', a manual drafted by the Legal Services of the European Commission, the European Parliament (EP) and the Council, the legal basis of an act, then, is 'the provision which confers competence to adopt the act in question' ( $p$. 26). This definition reflects that the concept of legal basis in the EU has the particular function, in contrast to domestic contexts, of operationalizing the foundational principle of conferred powers, according to which the Union can only act within the competences vested in it by its Member States.

Neither the Treaties nor the Court of Justice of the EU (CJEU), however, define the term 'legal basis'. Ambiguity can therefore exist regarding whether a particular provision constitutes a legal basis. On the contrary, the CJEU has developed a large body of case law on the issue of choosing the legal basis of EU legislation. The case law has largely revolved around the so-called 'centre of gravity' test according to which legal basis should be determined in line with the prevailing aim and content of an EU act where multiple legal bases are applicable (and mutually compatible). The following section includes excerpts from the most important CJEU rulings concerning the choice of legal basis - read them carefully and highlight the Court's most important findings in preparation for the test. Look up the cases and the contested acts where you need more context to understand the judgment. 


\section{CJEU case law}

Commission of the European Communities v Council of the European Communities (GSP) [1987]

\section{ECLI:EU:C:1987:163}

4 THE COMMISSION RAISES TWO SUBMISSIONS IN SUPPORT OF ITS ACTION, WHICH IN ITS VIEW MERGE INTO A SINGLE COMPLAINT : THE ABSENCE OF A PRECISE LEGAL BASIS, WHICH IS IN ITSELF CONTRARY TO ARTICLE 190 OF THE EEC TREATY, AND IN THIS CASE AT THE SAME TIME CONSTITUTES AN INFRINGEMENT OF THE TREATY BECAUSE IT RESULTED IN RECOURSE BEING HAD TO A PROCEDURE ENTAILING A UNANIMOUS VOTE RATHER THAN THE PROCEDURE APPLICABLE UNDER ARTICLE 113 OF THE TREATY, WHICH IN THE COMMISSION' S VIEW IS THE ONLY CORRECT LEGAL BASIS.

5 ARTICLE 190 OF THE TREATY PROVIDES THAT : "REGULATIONS, DIRECTIVES AND DECISIONS OF THE COUNCIL AND OF THE COMMISSION SHALL STATE THE REASONS ON WHICH THEY ARE BASED ". ACCORDING TO THE CASE-LAW OF THE COURT ( IN PARTICULAR THE JUDGMENT OF 7 JULY 1981 IN CASE 158/80 REWE-HANDELSGESELLSCHAFT NORD MBH V HAUPTZOLLAMT KIEL (( 1981 )) ECR 1805), IN ORDER TO SATISFY THAT REQUIREMENT TO STATE REASONS, COMMUNITY MEASURES MUST INCLUDE A STATEMENT OF THE FACTS AND LAW WHICH LED THE INSTITUTION IN QUESTION TO ADOPT THEM, SO AS TO MAKE POSSIBLE REVIEW BY THE COURT AND SO THAT THE MEMBER STATES AND THE NATIONALS CONCERNED MAY HAVE KNOWLEDGE OF THE CONDITIONS UNDER WHICH THE COMMUNITY INSTITUTIONS HAVE APPLIED THE TREATY.

6 IT IS THEREFORE NECESSARY TO CONSIDER WHETHER THE CONTESTED REGULATIONS SATISFY THOSE REQUIREMENTS.

7 IN THAT CONNECTION THE COUNCIL CONTENDS THAT, ALTHOUGH THE INDICATION OF THE LEGAL BASIS IS NOT PRECISE, THE RECITALS IN THE PREAMBLES TO THE REGULATIONS, TAKEN AS A WHOLE, PROVIDE SUFFICIENT ALTERNATIVE INFORMATION AS TO THE AIMS PURSUED BY THE COUNCIL, THAT IS TO SAY BOTH COMMERCIAL AIMS AND AIMS OF DEVELOPMENT-AID POLICY.

8 HOWEVER, THOSE INDICATIONS ARE NOT SUFFICIENT TO IDENTIFY THE LEGAL BASIS BY VIRTUE OF WHICH THE COUNCIL ACTED . ALTHOUGH THE RECITALS IN THE PREAMBLES TO THE REGULATIONS DO REFER TO IMPROVING ACCESS FOR DEVELOPING COUNTRIES TO THE MARKETS OF THE PREFERENCEGIVING COUNTRIES, THEY MERELY STATE THAT ADAPTATIONS TO THE COMMUNITY SYSTEM OF GENERALIZED PREFERENCES HAVE PROVED TO BE NECESSARY IN THE LIGHT OF EXPERIENCE IN THE FIRST 15 YEARS. MOREOVER, ACCORDING TO INFORMATION GIVEN THE COURT BY THE COUNCIL ITSELF, THE WORDING "HAVING REGARD TO THE TREATY" WAS ADOPTED AS A RESULT OF DIFFERENCES OF OPINION ABOUT THE CHOICE OF THE APPROPRIATE LEGAL BASIS. CONSEQUENTLY, THE WORDING CHOSEN WAS DESIGNED PRECISELY TO LEAVE THE LEGAL BASIS OF THE REGULATIONS IN QUESTION VAGUE

9 ADMITTEDLY, FAILURE TO REFER TO A PRECISE PROVISION OF THE TREATY NEED NOT NECESSARILY CONSTITUTE AN INFRINGEMENT OF ESSENTIAL PROCEDURAL REQUIREMENTS WHEN THE LEGAL BASIS FOR THE MEASURE MAY BE DETERMINED FROM OTHER PARTS OF THE MEASURE . HOWEVER, SUCH EXPLICIT REFERENCE IS INDISPENSABLE WHERE, IN ITS ABSENCE, THE PARTIES CONCERNED AND THE COURT ARE LEFT UNCERTAIN AS TO THE PRECISE LEGAL BASIS

10 IN ANSWER TO A QUESTION PUT BY THE COURT THE COUNCIL HAS STATED THAT WHEN IT ADOPTED THE CONTESTED REGULATIONS IT INTENDED TO BASE THEM ON BOTH ARTICLES 113 AND 235 OF THE EEC TREATY. IT HAS EXPLAINED THAT IT DEPARTED FROM THE COMMISSION' S PROPOSAL TO BASE THE REGULATIONS ON ARTICLE 113 ALONE BECAUSE IT WAS CONVINCED THAT THE CONTESTED 
REGULATIONS HAD NOT ONLY COMMERCIAL-POLICY AIMS, BUT ALSO MAJOR DEVELOPMENT-POLICY AIMS. THE IMPLEMENTATION OF DEVELOPMENT POLICY GOES BEYOND THE SCOPE OF ARTICLE 113 OF THE TREATY AND NECESSITATES RECOURSE TO ARTICLE 235.

11 IT MUST BE OBSERVED THAT IN THE CONTEXT OF THE ORGANIZATION OF THE POWERS OF THE COMMUNITY THE CHOICE OF THE LEGAL BASIS FOR A MEASURE MAY NOT DEPEND SIMPLY ON AN INSTITUTION' S CONVICTION AS TO THE OBJECTIVE PURSUED BUT MUST BE BASED ON OBJECTIVE FACTORS WHICH ARE AMENABLE TO JUDICIAL REVIEW .

12 IN THIS CASE, THE ARGUMENT WITH REGARD TO THE CORRECT LEGAL BASIS WAS NOT A PURELY FORMAL ONE, SINCE ARTICLES 113 AND 235 OF THE EEC TREATY ENTAIL DIFFERENT RULES REGARDING THE MANNER IN WHICH THE COUNCIL MAY ARRIVE AT ITS DECISION . THE CHOICE OF THE LEGAL BASIS COULD THUS AFFECT THE DETERMINATION OF THE CONTENT OF THE CONTESTED REGULATIONS .

13 IT FOLLOWS FROM THE VERY WORDING OF ARTICLE 235 THAT ITS USE AS THE LEGAL BASIS FOR A MEASURE IS JUSTIFIED ONLY WHERE NO OTHER PROVISION OF THE TREATY GIVES THE COMMUNITY INSTITUTIONS THE NECESSARY POWER TO ADOPT THE MEASURE IN QUESTION .

United Kinqdom of Great Britain and Northern Ireland v Council of the European Communities [1988] ECLI:EU:C:1988:85

4 THE APPLICANT, SUPPORTED IN ALL ESSENTIAL RESPECTS BY THE DANISH GOVERNMENT, CLAIMS THAT THE CONTESTED DIRECTIVE, WHICH WAS ADOPTED BY A QUALIFIED MAJORITY ON THE BASIS OF ARTICLE 43 OF THE TREATY, SHOULD HAVE BEEN BASED NOT ONLY ON THAT ARTICLE, BUT ALSO ON ARTICLE 100, WHICH REQUIRES UNANIMITY ON THE PART OF THE COUNCIL IT CONSIDERS THAT IT WAS NECESSARY TO BASE THE DIRECTIVE AT ISSUE ON THOSE TWO ARTICLES SINCE, IN ADDITION TO HAVING AGRICULTURAL POLICY OBJECTIVES, IT WAS DESIGNED INTER ALIA FOR THE PURPOSE OF APPROXIMATING THE PROVISIONS LAID DOWN BY LAW, REGULATION OR ADMINISTRATIVE ACTION IN THE MEMBER STATES TO SAFEGUARD THE INTERESTS AND HEALTH OF CONSUMERS. IN THE APPLICANT' S VIEW, THAT AIM IS NOT COVERED BY ARTICLE 43 OF THE TREATY BUT COMES UNDER ARTICLE 100 . PREVIOUS PRACTICE ON THE PART OF THE COUNCIL BEARS OUT THE NEED FOR THAT DUAL LEGAL BASIS

23 (...) THE COUNCIL DEPARTED FROM ITS PRACTICE OF BASING MEASURES IN THE FIELD IN QUESTION ON ARTICLES 43 AND 100 OF THE TREATY.

24 ON THAT POINT, IT SHOULD BE BORNE IN MIND THAT (...) IN THE CONTEXT OF THE ORGANIZATION OF THE POWERS OF THE COMMUNITY THE CHOICE OF THE LEGAL BASIS FOR A MEASURE MUST BE BASED ON OBJECTIVE FACTORS WHICH ARE AMENABLE TO JUDICIAL REVIEW . A MERE PRACTICE ON THE PART OF THE COUNCIL CANNOT DEROGATE FROM THE RULES LAID DOWN IN THE TREATY. SUCH A PRACTICE CANNOT THEREFORE CREATE A PRECEDENT BINDING ON COMMUNITY INSTITUTIONS WITH REGARD TO THE CORRECT LEGAL BASIS.

Commission of the European Communities v Council of the European Communities (Titanium Dioxide) [1991] ECLI:EU:C:1991:244

SUMMARY 
1. In the context of the organization of the powers of the Community the choice of the legal basis for a measure may not depend simply on an institution's conviction as to the objective pursued but must be based on objective factors which are amenable to judicial review. Those factors include in particular the aim and content of the measure.

2. Where an institution's power is based on two provisions of the Treaty, it is bound to adopt the relevant measures on the basis of the two relevant provisions. However, where, as in the case of Article 100a of the Treaty, one of the enabling provisions requires recourse to the cooperation procedure provided for in Article 149(2) of the Treaty, on conclusion of which the Council may act by a qualified majority provided that it intends accepting the amendments proposed by the Parliament and put forward by the Commission, and the other provision, as in the case of Article 130s, requires the Council to act unanimously after merely consulting the European Parliament, use of both of them as a joint legal basis would divest the cooperation procedure of its very substance, the purpose of that procedure being to increase the involvement of the European Parliament in the legislative process of the Community. That participation reflects a fundamental democratic principle that the peoples should take part in the exercise of power through the intermediary of a representative assembly. It follows that in such a case recourse to a dual legal basis is excluded and that it is necessary to determine which of those two provisions is the appropriate legal basis.

3 In view of the fact that, in the first place, it is apparent from the very terms of Article 130r(2) of the Treaty that a Community measure cannot be covered by Article 130 s merely because it pursues, among others, objectives of environmental protection, secondly, that action intended to approximate, in a given industrial sector, national rules concerning production conditions which were adopted for reasons relating to environmental protection but are liable to lead to distortions of competition, falls within the scope of Article 100a, since it is conducive to the attainment of the internal market, and, finally, that the objectives of environmental protection referred to in Article 130r may be effectively pursued by means of harmonizing measures adopted on the basis of Article 100a, the Council should have used Article 100a as the legal basis for Directive 89/428/EEC on procedures for harmonizing the programmes for the reduction and eventual elimination of pollution caused by waste from the titanium dioxide industry. Since the Council wrongly based the directive on Article 130s, the directive must be annulled.

Federal Republic of Germany v European Parliament and Council of the European Union (Tobacco Advertisina) [2000] ECLI:EU:C:2000:544

SUMMARY

1. Although the first indent of Article 129(4) of the Treaty (now, after amendment, the first indent of Article 152(4) EC) excludes any harmonisation of laws and regulations of the Member States designed to protect and improve human health, that provision does not mean that harmonising measures adopted on the basis of other provisions of the Treaty cannot have any impact on the protection of human health. The third paragraph of Article 129(1) provides that health requirements are to form a constituent part of the Community's other policies. Other articles of the Treaty may not, however, be used as a legal basis in order to circumvent the express exclusion of harmonisation laid down in Article 129(4) of the Treaty.

2. The measures referred to in Article 100a(1) of the Treaty (now, after amendment, Article 95(1) EC) are intended to improve the conditions for the establishment and functioning of the internal market. To construe that article as meaning that it vests in the Community legislature a general power to 
regulate the internal market would not only be contrary to the express wording of Articles 3(c) and 7a of the Treaty (now, after amendment, Articles 3(1)(c) EC and $14 \mathrm{EC}$ ) but would also be incompatible with the principle embodied in Article $3 \mathrm{~b}$ of the EC Treaty (now Article $5 \mathrm{EC}$ ) that the powers of the Community are limited to those specifically conferred on it.

Moreover, a measure adopted on the basis of Article 100a of the Treaty must genuinely have as its object the improvement of the conditions for the establishment and functioning of the internal market. Although recourse to Article 100a as a legal basis is possible if the aim is to prevent the emergence of future obstacles to trade resulting from multifarious development of national laws, the emergence of such obstacles must be likely and the measure in question must be designed to prevent them.

Those considerations also apply to interpretation of Article 57(2) of the Treaty (now, after amendment, Article 47(2) EC), read in conjunction with Article 66 of the Treaty (now Article $55 \mathrm{EC}$ ), those provisions being also intended to confer on the Community legislature specific power to adopt measures intended to improve the functioning of the internal market.

Furthermore, provided that the conditions for recourse to Articles 100a, 57(2) and 66 as a legal basis are fulfilled, the Community legislature cannot be prevented from relying on that legal basis on the ground that public health protection is a decisive factor in the choices to be made. On the contrary, the third paragraph of Article 129(1) of the Treaty (now, after amendment, the third paragraph of Article 152(1) EC) provides that health requirements are to form a constituent part of the Community's other policies and Article $100 \mathrm{a}(3)$ of the Treaty expressly requires that, in the process of harmonisation, a high level of human health protection is to be ensured.

3. Directive $98 / 43$ on the approximation of the laws, regulations and administrative provisions of the Member States relating to the advertising and sponsorship of tobacco products, adopted on the basis of Articles 57(2) of the Treaty (now, after amendment, Article 47(2) EC) 66 of the Treaty (now Article $55 \mathrm{EC}$ ) and 100a of the Treaty (now, after amendment, Article $95 \mathrm{EC}$ ) is annulled, since those articles do not constitute an appropriate legal basis for the directive.

On the one hand, although a directive prohibiting the advertising of tobacco products in periodicals, magazines and newspapers could be adopted on the basis of Article 100a of the Treaty with a view to ensuring the free movement of press products, for numerous types of advertising of tobacco products, the prohibition under Article 3(1) of the Directive cannot be justified by the need to eliminate obstacles to the free movement of advertising media or the freedom to provide services in the field of advertising. That applies, in particular, to the prohibition of advertising on posters, parasols, ashtrays and other articles used in hotels, restaurants and cafés, and the prohibition of advertising spots in cinemas, prohibitions which in no way help to facilitate trade in the products concerned. Moreover, the Directive does not ensure free movement of products which are in conformity with its provisions. On the Other hand, although appreciable distortion of competition could be a basis for recourse to Article 100a of the Treaty in order to prohibit certain forms of sponsorship, they are not such as to justify the use of that legal basis for an outright prohibition of advertising of the kind imposed by the Directive.

Accordingly, the Community legislature cannot rely on the need to eliminate obstacles to the free movement of advertising media and the freedom to provide services or on the need to eliminate distortions of competition, either in the advertising sector or in the tobacco products sector, in order to adopt the Directive on the basis of the above articles. 
European Parliament v Council of the European Union [2012] ECLI:EU:C:2012:472

42 According to settled case-law, the choice of the legal basis for a Community measure must rest on objective factors amenable to judicial review, which include the aim and content of that measure (see, in particular, Parliament $v$ Council, paragraph 34 and case-law cited).

43 If examination of a measure reveals that it pursues two aims or that it has two components and if one of those aims or components is identifiable as the main one, whereas the other is merely incidental, the measure must be founded on a single legal basis, namely, that required by the main or predominant aim or component (see, in particular, Parliament v Council, paragraph 35 and case-law cited)

44 With regard to a measure that simultaneously pursues a number of objectives, or that has several components, which are inseparably linked without one's being incidental to the other, the Court has held that, where various provisions of the Treaty are therefore applicable, such a measure will have to be founded, exceptionally, on the various corresponding legal bases (see, in particular, Parliament v Council, paragraph 36 and case-law cited).

45 None the less, the Court has held also, in particular in paragraphs 17 to 21 of Case C-300/89 Commission v Council [1991] ECR I-2867 ('Titanium dioxide'), that recourse to a dual legal basis is not possible where the procedures laid down for each legal basis are incompatible with each other (see, in particular, Parliament v Council, paragraph 37 and case-law cited).

46 If it was in the context of the cooperation procedure that the Court found, in Titanium dioxide, an incompatibility between that procedure, provided for by one of the two legal bases concerned in that judgment, and the Council's acting unanimously after merely consulting the European Parliament, provided for by the other, the Court has, nevertheless, in its subsequent decisions adopted a similar approach in connection with the procedure under Article $251 \mathrm{EC}$, known as 'the co-decision procedure' (see, to this effect, Case C-178/03 Commission v Parliament and Council [2006] ECR I-107, paragraphs 58 and 59, and Parliament v Council, paragraphs 76 to 79). Such an approach is still valid, after the entry into force of the Treaty of Lisbon, in the context of the ordinary legislative procedure.

47 In this instance, while Article 75 TFEU provides for application of the ordinary legislative procedure, which entails qualified majority voting in the Council and the Parliament's full participation in the procedure, Article 215(2) TFEU, for its part, entails merely informing the Parliament. In addition, recourse to Article 215(2) TFEU, unlike recourse to Article 75 TFEU, requires a previous decision in the sphere of the CFSP, namely, a decision adopted in accordance with Chapter 2 of Title V of the EU Treaty, providing for the adoption of restrictive measures such as those referred to in that provision. As a general rule, adoption of such a decision calls for unanimous voting in the Council acting alone.

48 Differences of that kind are such as to render those procedures incompatible.

49 It follows from the foregoing that, even if the contested regulation does pursue several objectives at the same time or have several components indissociably linked, without one's being secondary to the other, the differences in the procedures applicable under Articles 75 TFEU and 215(2) TFEU mean that it is not possible for the two provisions to be cumulated, one with the other, in order to serve as a twofold legal basis for a measure such as the contested regulation.

65 It follows from the foregoing that Article 215(2) TFEU may constitute the legal basis of restrictive measures, including those designed to combat terrorism, taken against natural or legal persons, groups or non-State entities by the Union when the decision to adopt those measures is part of the Union's action in the sphere of the CFSP. 
66 As the Advocate General observed in point 69 of his Opinion, in so far as Articles 75 TFEU and 215 TFEU relate to different European Union policies that pursue objectives which, although complementary, do not have the same scope, it would not seem possible to regard Article 75 TFEU as a more specific legal basis than Article 215(2) TFEU.

Kingdom of Spain v European Parliament and Council of the European Union [2015] ECLI:EU:C:2015:298

1 By its application, the Kingdom of Spain requests the annulment of Regulation (EU) No $1257 / 2012$ of the European Parliament and of the Council of 17 December 2012 implementing enhanced cooperation in the area of the creation of unitary patent protection (OJ 2012 L 361, p. 1) ('the contested regulation').

33 The Kingdom of Spain submits that the first paragraph of Article 118 TFEU was not an adequate legal basis for adopting the contested regulation and that the regulation must be deemed legally nonexistent. It is devoid of substantial content and its adoption has not been accompanied by measures providing uniform protection of intellectual property rights throughout the Union; nor does it bring about an approximation of the laws of the Member States for that purpose.

36 The Parliament and the Council maintain that Article 118 TFEU is an adequate legal basis for adopting the contested regulation. That provision does not require complete harmonisation of national laws so long as intellectual property rights are created which afford uniform protection in the participating Member States.

39 According to settled case-law, the choice of the legal basis for a European Union measure must rest on objective factors amenable to judicial review, which include in particular the aim and content of the measure (judgments in Commission v Council, C-377/12, EU:C:2014:1903, paragraph 34 and the case-law cited, and United Kingdom v Council, C-81/13, EU:C:2014:2449, paragraph 35).

40 It should be borne in mind that the first paragraph of Article 118 TFEU enables the EU legislature to establish measures for the creation of European intellectual property rights to provide uniform protection of intellectual property rights throughout the Union. That provision, inserted into the FEU Treaty by the Treaty of Lisbon, specifically refers to the establishment and functioning of the internal market, which falls within an area where the European Union has shared competence under Article 4 TFEU (see, to that effect, judgment in Spain and Italy v Council, C-274/11 and C-295/11, EU:C:2013:240, paragraphs 16 to 26).

41 The Court has also held, with regard to the expression 'throughout the Union' used in that provision, that, since the power conferred by that article is exercised within the ambit of enhanced cooperation, the European intellectual property right so created and the uniform protection given by it must be in force, not in the Union in its entirety, but only in the territory of the participating Member States (see, to that effect, judgment in Spain and Italy v Council, C-274/11 and C-295/11, EU:C:2013:240, paragraphs 67 and 68).

42 Consequently, it is necessary to determine, in the light of the aim and content of the contested regulation, whether that regulation establishes measures providing uniform protection of intellectual property rights in the territory of the participating Member States and, accordingly, whether - as is argued by the Parliament, the Council and the interveners - it was validly based on the first paragraph of Article 118 TFEU, which is cited as the legal basis in the preamble to that regulation. 
43 Regarding the aim of the contested regulation, it should be noted that, pursuant to Article 1(1) thereof, the objective of that regulation is 'the creation of unitary patent protection' which, according to recital 1 of that regulation, should feature amongst the legal instruments which undertakings have at their disposal so as to enable those undertakings to adapt their activities in manufacturing and distributing products across national borders. Recital 4 of that regulation confirms that objective by emphasising the need to improve the level of patent protection by making it possible for undertakings to obtain uniform protection in the participating Member States and the need to eliminate costs and complexity for undertakings throughout the Union.

44 So far as the content of the contested regulation is concerned, it is clear that the provisions of that regulation give expression, through their definition of the characteristics of the EPUE, to the EU legislature's desire to provide uniform protection in the territory of the participating Member States.

50 Moreover, in recital 9 of the contested regulation, the EU legislature stated that in matters not covered by that regulation or by Regulation No $1260 / 2012$ the scope and limitations of the right conferred on the proprietor of a European patent with unitary effect to prevent any third party from committing acts against which that patent provides protection in the territory of all the participating Member States in which it has unitary effect should apply.

51 It follows from the foregoing that the unitary patent protection established by the contested regulation is apt to prevent divergences in terms of patent protection in the participating Member States and, accordingly, provides uniform protection within the meaning of the first paragraph of Article 118 TFEU.

52 It follows that that provision is an adequate legal basis for the adoption of the contested regulation. 


\section{DRAFT LEGISLATION “A”}

DIRECTIVE .../...

of ... November 2018

facilitating the cross-border exchange of information on road safety related traffic offences

Having regard to the Treaty on the Functioning of the European Union, and in particular ...,

Having regard to the proposal from the European Commission,

(...)

Whereas:

(1)Improving road safety is a prime objective of the Union's transport policy. The Union is pursuing a policy to improve road safety with the objective of reducing fatalities, injuries and material damage. An important element of that policy is the consistent enforcement of sanctions for road traffic offences committed in the Union which considerably jeopardise road safety.

(2) Greater convergence of control measures between Member States should also be encouraged and the Commission should examine in this respect the need for developing common standards for automatic checking equipment for road safety controls.

(3)The awareness of Union citizens should be raised as regards the road safety traffic rules in force in different Member States and as regards the implementation of this Directive, in particular through appropriate measures guaranteeing the provision of sufficient information on the consequences of not respecting the road safety traffic rules when travelling in a Member State other than the Member State of registration.

(4)In order to improve road safety throughout the Union and to ensure equal treatment of drivers, namely resident and non-resident offenders, enforcement should be facilitated irrespective of the Member State of registration of the vehicle. To this end, a system of cross-border exchange of information should be put in place for certain identified road safety related traffic offences, regardless of their administrative or criminal nature under the law of the Member State concerned, granting the Member State of the offence access to vehicle registration data (VRD) of the Member State of registration.

(5)A more efficient cross-border exchange of VRD, which should facilitate the identification of persons suspected of committing a road safety related traffic offence, may increase the deterrent effect and induce more cautious behaviour by the driver of a vehicle that is registered in a Member State other than the Member State of the offence, thereby preventing casualties due to road traffic accidents.

(6)The road safety related traffic offences covered by this Directive are not subject to homogeneous treatment in the Member States. Some Member States qualify such offences under national law as administrative' offences while others qualify them as 'criminal. offences. This Directive should apply regardless of how those offences are qualified under national law. 
(7)Existing software applications should be the basis for the data exchange under this Directive and should, at the same time, also facilitate the reporting by Member States to the Commission. Such applications should provide for the expeditious, secure and confidential exchange of specific VRD between Member States. Advantage should be taken of the European Vehicle and Driving Licence Information System (Eucaris) software application. The Commission should report on an assessment of the functioning of the software applications used for the purposes of this Directive.

(8)Member States should be able to contact the owner, the holder of the vehicle or the otherwise identified person suspected of committing the road safety related traffic offence in order to keep the person concerned informed of the applicable procedures and the legal consequences under the law of the Member State of the offence. In doing so, Member States should consider sending the information concerning road safety related traffic offences in the language of the registration documents or the language most likely to be understood by the person concerned, to ensure that that person has a clear understanding of the information which is being shared with the person concerned. Member States should apply the appropriate procedures to ensure that only the person concerned is informed and not a third party. To that effect, Member States should use detailed arrangements similar to those adopted for following up such offences including means such as, where appropriate, registered delivery. This will allow that person to respond to the information in an appropriate way, in particular by asking for more information, settling the fine or by exercising his/her rights of defence, in particular in the case of mistaken identity.

(9)With a view to pursuing a road safety policy aiming for a high level of protection for all road users in the Union and taking into account the widely differing circumstances pertaining within the Union, Member States should act, without prejudice to more restrictive policies and laws, in order to ensure greater convergence of road traffic rules and of their enforcement between Member States. In the framework of its report to the European Parliament and to the Council on the application of this Directive, the

Commission should examine the need to develop common standards in order to establish comparable methods, practices and minimum standards at Union level taking into account international cooperation and existing agreements in the field of road safety, in particular the Vienna Convention on Road Traffic of 8 November 1968.

\section{HAVE ADOPTED THIS DIRECTIVE:}

\section{Article 1}

\section{Objective}

This Directive aims to ensure a high level of protection for all road users in the Union by facilitating the cross-border exchange of information on road safety related traffic offences and thereby the enforcement of sanctions, where those offences are committed with a vehicle registered in a Member State other than the Member State where the offence took place. 
This Directive shall apply to the following road safety related traffic offences:

$$
\begin{aligned}
& \text { (a) speeding; } \\
& \text { (b) non-use of a seat-belt; }
\end{aligned}
$$

(c) failing to stop at a red traffic light;

$$
\text { (d) drink-driving; }
$$

(e) driving under the influence of drugs;

(f) failing to wear a safety helmet;

(g) use of a forbidden lane;

(h)illegally using a mobile telephone or any other communication devices while driving.

$$
\text { Article } 3
$$

\section{Procedure for the exchange of information between Member States}

1. For the investigation of the road safety related traffic offences referred to in Article 2, the Member States shall allow other Member States' national contact points, access to the following national VRD, with the power to conduct automated searches on:

(a) data relating to vehicles; and

(b) data relating to owners or holders of the vehicle.

2. Any searches in the form of outgoing requests shall be conducted by the national contact point of the Member State of the offence using a full registration number.

Those searches shall be conducted in compliance with the procedures as described in Chapter 3 of the Annex to Decision 2008/616/JHA.

The Member State of the offence shall, under this Directive, use the data obtained in order to establish who is personally liable for road safety related traffic offences referred to in Articles

Article 4

Information letter on the road safety related traffic offence

1. The Member State of the offence shall decide whether to initiate follow-up proceedings in relation to the road safety related traffic offences referred to in Article 2 or not.

In the event that the Member State of the offence decides to initiate such proceedings, that Member State shall, in conformity with its national law, inform the owner, the holder of the vehicle or the otherwise identified person suspected of committing the road safety related traffic offence accordingly.

This information shall, as applicable under national law, include the legal consequences thereof within the territory of the Member State of the offence under the law of that Member State. 
2. When sending the information letter to the owner, the holder of the vehicle or the otherwise identified person suspected of committing the road safety related traffic offence, the Member State of the offence shall, in accordance with its law, include any relevant information, notably the nature of the road safety related traffic offence referred to in Article 2 , the place, date and time of the offence, the title of the texts of the national law infringed and the sanction and, where appropriate, data concerning the device used for detecting the offence.

\section{Article 6}

\section{Data protection}

1. The provisions on data protection set out in Framework Decision 2008/977/JHA shall apply to personal data processed under this Directive.

2. In particular, each Member State shall ensure that personal data processed under this Directive are, within an appropriate time period, rectified if inaccurate, or erased or blocked when they are no longer required, in accordance with Articles 4 and 5 of Framework Decision 2008/977/JHA, and that a time limit for the storage of data is established in accordance with Article 9 of that Framework Decision.

Member States shall ensure that all personal data processed under this Directive are only used for the objective set out in Article 1, and that the data subjects have the same rights to information to access, to rectification, erasure and blocking, to compensation and to judicial redress as those adopted under national law in implementation of relevant provisions of Framework Decision 2008/977/JHA

Article 7

\section{Information for road users in the Union}

1. The Commission shall make available on its website a summary in all official languages of the institutions of the Union of the rules in force in Member States in the field covered by this Directive. Member States shall provide information on these rules to the Commission.

2. Member States shall provide road users with the necessary information about the rules applicable in their territory and the measures implementing this Directive in association with, among other organisations, road safety bodies, non-governmental organisations active in the field of road safety and automobile clubs. 


\section{DRAFT LEGISLATION "B"}

DIRECTIVE .../...

of ... November 2018

amending Directive 2006/112/EC and Directive 2009/132/EC as regards certain value added tax obligations for supplies of services and distance sales of goods

Having regard to the Treaty on the Functioning of the European Union, and in particular ...,

Having regard to the proposal from the European Commission,

(..)

Whereas:

(1)Council Directive 2006/112/EC provides for special schemes for charging value added tax (VAT) for non-established taxable persons providing telecommunications, broadcasting or electronically supplied services to non-taxable persons.

(2)Council Directive 2009/132/EC provides for an exemption from VAT of imports of small consignments of negligible value.

(5)To avoid that taxable persons supplying services other than telecommunications, broadcasting or electronically supplied services to non-taxable persons have to be identified for VAT purposes in each and every Member State where those services are subject to VAT, Member States should permit taxable persons supplying such services to make use of the IT system for registration and for declaration and payment of the VAT allowing them to declare and pay VAT on those services in a single Member State.

(6)The realisation of the internal market, globalisation, and technological change have resulted in an explosive growth of electronic commerce and, hence, of distance sales of goods, both supplied from one Member State to another and from third territories or third countries to the Community. To clearly determine the scope of the measures applying to intra-Community distance sales of goods and distance sales of goods imported from third territories or third countries, those concepts should be defined.

(10)The scope of the special scheme for distance sales of goods imported from third territories or third countries should be restricted to sales of goods of an intrinsic value not exceeding EUR 150 that are dispatched directly from a third territory or third country to a customer in the Community, as of which a full customs declaration is required for customs purposes upon importation. Goods subject to excise duty should be excluded from its scope as excise duty is part of the taxable amount for VAT upon importation.

(12)A taxable person making use of the special scheme for distance sales of goods imported from third territories or third countries should be allowed to appoint an intermediary established in the Community as the person liable for payment of the VAT and to fulfil the obligations laid down in that special scheme in his name and on his behalf.

(13)In order to protect Member States' tax revenue, a taxable person not established in the Community making use of this special scheme should be obliged to designate an intermediary. However, that obligation should not apply if he is established in a country with which the Union has concluded an agreement on mutual assistance.

(15)Following the explosive growth of electronic commerce and the resulting increase in the number of small consignments of an intrinsic value not exceeding EUR 150 imported in the Community, Member States should systematically permit the use of special arrangements for declaration and payment of import VAT.

HAVE ADOPTED THIS DIRECTIVE: 
Article 1

Amendments to Directive 2006/112/EC with effect from 1 January 2019

With effect from 1 January 2019, Directive 2006/112/EC is amended as follows:

(1)Article 58 is replaced by the following:

'Article 58

1. The place of supply of the following services to a non-taxable person shall be the place where that person is established, has his permanent address or usually resides:

(a) telecommunications services;

(b) radio and television broadcasting services;

(c) electronically supplied services, in particular those referred to in Annex II.

Where the supplier of a service and the customer communicate via electronic mail, that shall not of itself mean that the service supplied is an electronically supplied service.

2. Paragraph 1 shall not apply where the following conditions are met:

(a)the supplier is established or, in the absence of an establishment, has his permanen address or usually resides in only one Member State; and

(b)services are supplied to non-taxable persons who are established, have their permanent address or usually reside in any Member State other than the Member State referred to in point (a); and

(c)the total value, exclusive of VAT, of the supplies referred to in point (b) does not in the current calendar year exceed EUR 10000 , or the equivalent in national currency, and did not do so in the course of the preceding calendar year.

(2)Article $219 \mathrm{a}$ is replaced by the following:

'Article 219a

1. Invoicing shall be subject to the following rules:

(a)the rules applying in the Member State in which the supplier has established his business or has a fixed establishment from which the supply is made or, in the absence of such place of establishment or fixed establishment, the Member State where the supplier has his permanent address or usually resides, where:

(i)the supplier is not established in the Member State in which the supply of goods or services is deemed to be made, in accordance with the provisions of Title V, or his establishment in that Member State does not intervene in the supply within the meaning of point (b) of Article 192a, and the person liable for the payment of the VAT is the person to whom the goods or services are supplied unless the customer issues the invoice (self-billing);

(ii)the supply of goods or services is deemed not to be made within the Community, in accordance with the provisions of Title V; 


\section{Treaty provisions}

\section{Article 26 TFEU}

1. The Union shall adopt measures with the aim of establishing or ensuring the functioning of the internal market, in accordance with the relevant provisions of the Treaties.

2. The internal market shall comprise an area without internal frontiers in which the free movement of goods, persons, services and capital is ensured in accordance with the provisions of the Treaties.

3. The Council, on a proposal from the Commission, shall determine the guidelines and conditions necessary to ensure balanced progress in all the sectors concerned.

Article 87 TFEU

1. The Union shall establish police cooperation involving all the Member States' competent authorities, including police, customs and other specialised law enforcement services in relation to the prevention, detection and investigation of criminal offences.

2. For the purposes of paragraph 1, the European Parliament and the Council, acting in accordance with the ordinary legislative procedure, may establish measures concerning

(a) the collection, storage, processing, analysis and exchange of relevant information;

(b) support for the training of staff, and cooperation on the exchange of staff, on equipment and on research into crime-detection

(c) common investigative techniques in relation to the detection of serious forms of organised crime.

3. The Council, acting in accordance with a special legislative procedure, may establish measures concerning operational cooperation between the authorities referred to in this Article. The Council shall act unanimously after consulting the European Parliament.

In case of the absence of unanimity in the Council, a group of at least nine Member States may request that the draft measures be referred to the European Council. In that case, the procedure in the Council shall be suspended. After discussion, and in case of a consensus, the European Council shall, within four months of this suspension, refer the draft back to the Council for adoption.

Within the same timeframe, in case of disagreement, and if at least nine Member States wish to establish enhanced cooperation on the basis of the draft measures concerned, they shall notify the European Parliament, the Council and the Commission accordingly. In such a case, the authorisation to proceed with enhanced cooperation referred to in Article 20(2) of the Treaty on European Union and Article 329(1) of this Treaty shall be deemed to be granted and the provisions on enhanced cooperation shall apply.

The specific procedure provided for in the second and third subparagraphs shall not apply to acts which constitute a development of the Schengen acquis. 


\section{Article 90 TFEU}

The objectives of the Treaties shall, in matters governed by this Title, be pursued within the framework of a common transport policy.

\section{Article 91 TFEU}

1. For the purpose of implementing Article 90, and taking into account the distinctive features of transport, the European Parliament and the Council shall, acting in accordance with the ordinary legislative procedure and after consulting the Economic and Social Committee and the Committee of the Regions, lay down:

(a) common rules applicable to international transport to or from the territory of a Member State or passing across the territory of one or more Member States;

(b) the conditions under which non-resident carriers may operate transport services within a Member State;

(c) measures to improve transport safety;

(d) any other appropriate provisions.

2. When the measures referred to in paragraph 1 are adopted, account shall be taken of cases where their application might seriously affect the standard of living and level of employment in certain regions, and the operation of transport facilities.

\section{Article 113 TFEU}

The Council shall, acting unanimously in accordance with a special legislative procedure and after consulting the European Parliament and the Economic and Social Committee, adopt provisions for the harmonisation of legislation concerning turnover taxes, excise duties and other forms of indirect taxation to the extent that such harmonisation is necessary to ensure the establishment and the functioning of the internal market and to avoid distortion of competition.

\section{Article 114 TFEU}

1. Save where otherwise provided in the Treaties, the following provisions shall apply for the achievement of the objectives set out in Article 26. The European Parliament and the Council shall, acting in accordance with the ordinary legislative procedure and after consulting the Economic and Social Committee, adopt the measures for the approximation of the provisions laid down by law, regulation or administrative action in Member States which have as their object the establishment and functioning of the internal market.

2. Paragraph 1 shall not apply to fiscal provisions, to those relating to the free movement of persons nor to those relating to the rights and interests of employed persons.

3. The Commission, in its proposals envisaged in paragraph 1 concerning health, safety, environmental protection and consumer protection, will take as a base a high level of protection, taking account in particular of any new development based on scientific facts. Within their respective powers, the European Parliament and the Council will also seek to achieve this objective. 